University of Nebraska - Lincoln

DigitalCommons@University of Nebraska - Lincoln

USDA National Wildlife Research Center - Staff Publications
U.S. Department of Agriculture: Animal and Plant Health Inspection Service

2012

\title{
Environmental temperatures, physiology and behavior limit the range expansion of invasive Burmese pythons in southeastern USA
}

\author{
Elliott L.R. Jacobson \\ University of Florida, jacobsone@ufl.edu \\ David G. Barker \\ Vida Preciosa International (VPI), vpi@beecreek.net \\ Tracy M. Barker \\ Vida Preciosa International (VPI),, tbarker@beecreek.net \\ Richard Mauldin \\ US Department of Agriculture \\ Michael L. Avery \\ US Department of Agriculture, michael.I.avery@aphis.usda.gov
}

See next page for additional authors

Follow this and additional works at: https://digitalcommons.unl.edu/icwdm_usdanwrc

Jacobson, Elliott L.R.; Barker, David G.; Barker, Tracy M.; Mauldin, Richard; Avery, Michael L.; Engeman, Richard M.; and Secor, Stephen, "Environmental temperatures, physiology and behavior limit the range expansion of invasive Burmese pythons in southeastern USA" (2012). USDA National Wildlife Research Center - Staff Publications. 1151.

https://digitalcommons.unl.edu/icwdm_usdanwrc/1151

This Article is brought to you for free and open access by the U.S. Department of Agriculture: Animal and Plant Health Inspection Service at DigitalCommons@University of Nebraska - Lincoln. It has been accepted for inclusion in USDA National Wildlife Research Center - Staff Publications by an authorized administrator of DigitalCommons@University of Nebraska - Lincoln. 


\section{Authors}

Elliott L.R. Jacobson, David G. Barker, Tracy M. Barker, Richard Mauldin, Michael L. Avery, Richard M. Engeman, and Stephen Secor 


\title{
Environmental temperatures, physiology and behavior limit the range expansion of invasive Burmese pythons in southeastern USA
}

\author{
Elliott R. JACOBSON, ${ }^{1}$ David G. BARKER, ${ }^{2}$ Tracy M. BARKER,${ }^{2}$ Richard MAULDIN, ${ }^{3}$ Michael \\ L. AVERY, ${ }^{4}$ Richard ENGEMAN ${ }^{3}$ and Stephen SECOR $^{5}$ \\ ${ }^{1}$ College of Veterinary Medicine, University of Florida, Gainesville, Florida, ${ }^{2}$ Vida Preciosa International (VPI), Boerne, Texas, \\ ${ }^{3}$ US Department of Agriculture, Wildlife Services, National Wildlife Research Center, Fort Collins, Colorado, ${ }^{4}$ US Department of \\ Agriculture, Wildlife Services, National Wildlife Research Center, Gainesville, Florida and ${ }^{5}$ Department of Biological Sciences, \\ University of Alabama, Tuscaloosa, Alabama, USA
}

\begin{abstract}
A well-established population of Burmese pythons resides in the Everglades of southern Florida. Prompted in part by a report that identified much of southern USA as suitable habitat for expansion or establishment of the Burmese python, we examined the plausibility of this snake to survive winters at sites north of the Everglades. We integrated daily low and high temperatures recorded from October to February from 2005-2011 at Homestead, Orlando and Gainesville, Florida; and Aiken, South Carolina, with minimum temperatures projected for python digestion $\left(16{ }^{\circ} \mathrm{C}\right)$, activity $\left(5^{\circ} \mathrm{C}\right)$ and survival $\left(0{ }^{\circ} \mathrm{C}\right)$. Mean low and high temperatures decreased northward from Homestead to Aiken and the number of days of freezing temperatures increased northward. Digestion was impaired or inhibited for 2 months in the Everglades and up to at least 5 months in Aiken, and activity was increasingly limited northward during these months. Reports of overwinter survivorship document that a single bout of low and freezing temperatures results in python death. The capacity for Burmese pythons to successfully overwinter in more temperate regions of the USA is seemingly prohibited because they lack the behaviors to seek refuge from, and the physiology to tolerate, cold temperatures. As tropical Southeast Asia is the source of the Everglades Burmese pythons, we predict it is unlikely that they will be able to successfully expand to or colonize more temperate areas of Florida and adjoining states due to their lack of behavioral and physiological traits to seek refuge from cold temperatures.
\end{abstract}

Key words: ambient temperature, Burmese python, invasion, snake, thermal tolerance

\section{INTRODUCTION}

Correspondence: Elliott R. Jacobson, SACS, Building 2015, College of Veterinary Medicine, University of Florida,

Gainesville, Florida 32608, USA.

Email: jacobsone@ufl.edu
The zoogeography of snakes and other reptiles is markedly influenced by a number of environmental factors, with ambient temperature $\left(\mathrm{T}_{\mathrm{a}}\right)$ being a critical factor that affects their distribution and seasonal activity 
patterns. For example, two-thirds of the global variation in reptile richness can be explained by temperature alone (Qian 2010). Reptile diversity peaks in the tropics and decreases with an increase in latitude, with only 1 snake species (Vipera berus Linnaeus, 1758) reaching the Arctic Circle and none reaching the Antarctic Circle (Darlington 1966; Arnold 1972; Schall \& Pianka 1978; Saint Girons 1980).

For reptiles inhabiting the tropics, thermoregulation is relatively passive as $T_{a}$ is generally stable and conducive to normal activity (Avery 1982; Huey 1982). For water pythons (Liasis fuscus Peters, 1873) inhabiting tropical Australia, few features of its ecology are influenced by thermoregulation (Shine \& Madsen 1996). Reptiles inhabiting temperate regions of the world tend to experience much greater temporal variation in $\mathrm{T}_{\mathrm{a}}$ than tropical species, with seasonal (as well as daily) oscillations in $\mathrm{T}_{\mathrm{a}}$ that span beyond a species critical thermal maximum $\left(\mathrm{CT}_{\max }\right.$; high temperature at which activity is impaired and with no ability to escape will lead to death) and below their critical thermal minimum $\left(\mathrm{CT}_{\min }\right.$; low temperature at which activity is likewise impaired and with no ability to escape will lead to death) (Cowles \& Bogert 1944; Avery 1982; Huey 1982). Whereas all reptiles regulate body temperate to achieve an optimal range of performances, temperate reptiles need also to avoid exposure to $\mathrm{T}_{\mathrm{a}}$ that exceed $\mathrm{CT}_{\max }$ and, more importantly, possess a suite of adaptive behaviors to escape and survive a yearly episode of low $\mathrm{T}_{\mathrm{a}}$ (Peterson et al. 1993). As ectotherms, reptiles respond to a lowering of $\mathrm{T}_{\mathrm{a}}$ with a progressive depression of metabolic rate and performance that continues until the attainment of their $\mathrm{CT}_{\text {min }}$ and below which death is likely from hypothermia or freezing (Peterson et al. 1993). Therefore, with the lowering of $\mathrm{T}_{\mathrm{a}}$ with the onset of winter, temperate reptiles characteristically retreat to underground refugia and remain dormant (i.e. hibernate or brumate) until $\mathrm{T}_{\mathrm{a}}$ increases in the spring and they reemerge (Gregory 1992).

Due to a climate that ranges from temperate in the north to subtropical to tropical in the south, an array of reptiles and amphibians have become introduced and established in Florida, with many of these introductions originating through the pet trade (Krysko et al. 2011; Meshaka 2011). In Florida, thermal requirements affect the diversity of these invasive species in a north to south direction, with the greatest number of species in the southern portion of the state, where there are very few days of freezing temperatures in any 1 year. Of intro- duced species, the Burmese python (accepted name $P y$ thon molurus bivittatus Kuhl, 1820 by some biologists [Reed \& Rodda 2009] and synonymously P. bivittatus Kuhl, 1820 by others [Jacobs et al. 2009]) has become an established nonnative species in the Everglades of extreme southern Florida (Reed \& Rodda 2009; Engeman et al. 2011; Krysko et al. 2011). The Burmese python, one of the largest species of snakes in the world, naturally occurs in tropical and subtropical regions of Southeast Asia, where it prefers covered terrestrial habitats (e.g. forest, jungle and scrub) and access to water (Murphy \& Henderson 1997). The Burmese python's recent establishment in the Everglades stems from a preadaptation to mild winter temperatures, the physical environment that is available (e.g. scrub savanna, flooded grassland and canals) and the food resources (over 25 species of birds have been found in the digestive tract of Burmese pythons; Dove et al. 2011) that can be found in this region of Florida. To assess the potential expansion or establishment of Burmese pythons, different species distribution models (SDMs) have been used to infer the potential range limits within the continental USA (Pyron et al. 2008; Rodda et al. 2009; Van Wilgen et al. 2009).

The consideration of python physiology, the profile of winter temperature for areas north of the Everglades and within the range of suitable climate projected by Rodda et al. (2009), and the recent reports on overwinter death of Burmese pythons (Avery et al. 2010; Dorcas et al. 2011; Mazzotti et al. 2011) lead us to explore the likelihood of the Burmese python to expand its distribution northward, or to independently establish a new population north of the Everglades. First we ask: Is the environment north of the Everglades conducive for python long-term survival? Next we ask: Do Burmese pythons currently inhabiting the Everglades possess the ecological, physiological and behavioral traits to survive in more temperate environments? We have examined these questions by: (i) integrating recorded low and high temperatures from October to February for the past 6 fallwinter periods from 4 sites (Homestead, Orlando and Gainesville, Florida and Aiken, South Carolina) with the projected minimum temperature limits of python digestion, activity and survival; (ii) incorporating these temperature data with recent reports on overwinter death of Burmese python in the Everglades, Gainesville and Aiken; and (iii) discussing if Burmese pythons possess the behaviors and physiology to cope with and survive winter temperatures. 


\section{MATERIALS AND METHODS}

\section{Species account}

Burmese pythons, native to Southeast Asia, hatch at 46-74 cm in total length (TL), with an average weight of $115 \mathrm{~g}$ (de Vosjoli 1991). Older males (>10 years) typically measure $3.0-4.0 \mathrm{~m}$ TL and $18 \mathrm{~kg}-50 \mathrm{~kg}$ in mass, whereas most older females measure 3.5-4.7 m TL and weigh $29.5-75 \mathrm{~kg}$ (Barker et al. 2012). In captivity, female Burmese pythons may reach sexual maturity as early as 18 months, generally breed between November and March and lay eggs 65-120 days after breeding (de Vosjoli 1991; D. G. Barker, unpubl. data). Eggs (8-107 per clutch) hatch 53-88 days after being laid, the duration dependent on incubation temperatures. Female Burmese pythons brood their eggs by coiling tightly around them and use shivering thermogenesis to raise their body temperature and clutch temperature $6-8{ }^{\circ} \mathrm{C}$ above ambient temperature (Vinegar et al. 1970; Van Mierop \& Bernard 1978). In captivity, Burmese pythons can live up to 30 years. The first recorded capture of a Burmese python in the Everglades was in 1979; however, it was not until 1995 that individuals, including juveniles, were being captured on a regular basis (Snow et al. 2007). In 2002, the first neonates were discovered in Everglades National Park (ENP), and since that year until 2010, the number of Burmese pythons removed per year steadily increased (from 14 to 322 ). Based on preliminary data, 130 were removed in 2011 (http://www. nps.gov/ever/naturescience/burmesepython.htm).

\section{Temperature data}

We obtained hourly ambient air temperatures $\left(\mathrm{T}_{\mathrm{a}}\right.$; www.weathersource.com) for Aiken $\left(33^{\circ} 39^{\prime} \mathrm{N}\right.$, $\left.81^{\circ} 41^{\prime} \mathrm{W}\right)$, Gainesville $\left(29^{\circ} 42^{\prime} \mathrm{N}, 82^{\circ} 17^{\prime} \mathrm{W}\right)$, Orlando $\left(28^{\circ} 26^{\prime} \mathrm{N}, 81^{\circ} 20^{\prime} \mathrm{W}\right)$ and Homestead $\left(25^{\circ} 29^{\prime} \mathrm{N}, 80^{\circ} 23^{\prime} \mathrm{W}\right)$ for October to February 2005-2011. These months were selected because they include the period during which the first cold front passes through southeastern USA and the coldest days of the year in Florida. These sites were selected because they are located within the geographic climate envelope predicted to be suitable for the establishment of Burmese pythons, as modeled by Rodda et al. (2009) (Fig. 1), and include localities (Gainesville and Aiken) where the overwinter survivorship of the Burmese python has been examined (Avery et al. 2010; Dorcas et al. 2011). At each site, monthly mean low and high temperatures were calculated. Although the $\mathrm{CT}_{\text {min }}$ has not been experimentally identified for Burmese pythons, studies have established that the $\mathrm{CT}_{\min }$ of certain

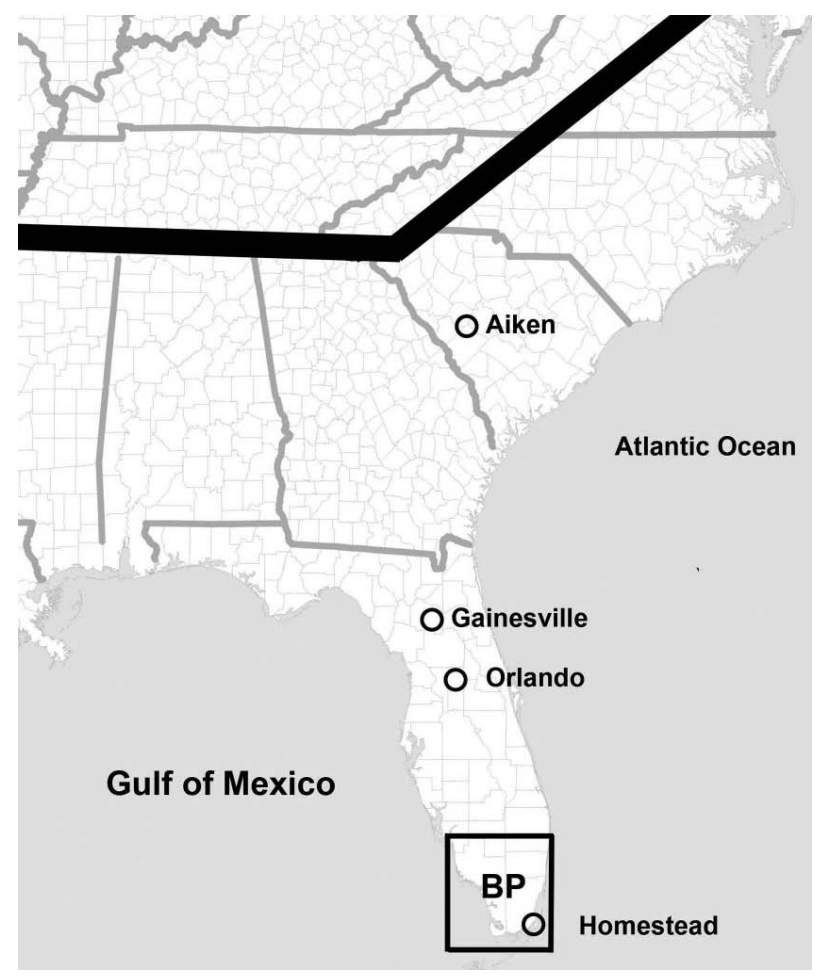

Figure 1 Approximate limits of distribution (area below black line) of the Burmese python in southeastern USA based on a climate-matching model by Rodda et al. (2009). The approximate current range in southern Florida is indicated (BP).

temperate species of snakes is approximately $5{ }^{\circ} \mathrm{C}(\mathrm{Ja}-$ cobson \& Whitford 1970; Doughty 1994). Therefore, we select $5{ }^{\circ} \mathrm{C}$ as a conservative estimate of the $\mathrm{CT}_{\min }$ of the Burmese python. In a study to examine temperature effects on postprandial metabolism of the Burmese python, no snakes consumed a mouse meal at $20^{\circ} \mathrm{C}$, but all fed after temperature was increased to $30^{\circ} \mathrm{C}$. Subsequently, after the temperature was reduced to $20^{\circ} \mathrm{C}, 9$ of 10 snakes regurgitated within 2-5 days after feeding (Wang et al. 2003). Therefore, we conservatively select $16{ }^{\circ} \mathrm{C}$ or less as a body temperature at which Burmese pythons are unable to digest a meal.

We used these temperature data to present 4 sets of information. First, to demonstrate the northern cline in $\mathrm{T}_{\mathrm{a}}$, we tabulated for each site and each fall-winter period the mean low and high $\mathrm{T}_{\mathrm{a}}$ for each month from October to February. Second, to identify the extent that Burmese pythons are theoretically thermally challenged, we tabulated for each site and each fall-winter period, the number of days that $\mathrm{T}_{\mathrm{a}}$ never exceeded $16^{\circ} \mathrm{C}$ (prohibit- 
ing digestion), $5{ }^{\circ} \mathrm{C}\left(\mathrm{CT}_{\min }\right)$ and $0{ }^{\circ} \mathrm{C}$ (lethal minimum). Third, we performed a similar tabulation to provide the number of days that $T_{a}$ dropped (for any length of time) to 16,5 and $0{ }^{\circ} \mathrm{C}$. Fourth, to illustrate the onset of decreasing temperatures in the fall, the episodic nature of daily temperatures during these months and the spans of time that $\mathrm{T}_{\mathrm{a}}$ are below 16,5 and $0{ }^{\circ} \mathrm{C}$ for each site and fall-winter year, we present profiles of daily minimum and maximum temperatures that overlay the physiological critical temperatures of 16,5 and $0{ }^{\circ} \mathrm{C}$.

\section{RESULTS}

Monthly mean $( \pm \mathrm{SD})$ low and high $\mathrm{T}_{\mathrm{a}} \mathrm{s}$ from October to February decreased northward from Homestead, to Orlando, to Gainesville and to Aiken (Table 1). For

Table 1 Mean $( \pm \mathrm{SD})$ high and low air temperatures $\left({ }^{\circ} \mathrm{C}\right)$ for Homestead, Orlando and Gainesville, Florida and Aiken, South Carolina, October-February, 2005-2011

\begin{tabular}{|c|c|c|c|c|c|c|c|c|c|c|}
\hline \multirow{2}{*}{ Year } & \multicolumn{2}{|l|}{ October } & \multicolumn{2}{|l|}{ November } & \multicolumn{2}{|l|}{ December } & \multicolumn{2}{|l|}{ January } & \multicolumn{2}{|l|}{ February } \\
\hline & High & Low & High & Low & High & Low & High & Low & High & Low \\
\hline \multicolumn{11}{|c|}{ Homestead, Florida } \\
\hline 2005-2006 & $29( \pm 2.9)$ & $21( \pm 4.0)$ & $27( \pm 1.9)$ & $17( \pm 3.4)$ & $25( \pm 2.8)$ & $13( \pm 4.2)$ & $24( \pm 3.2)$ & $13( \pm 4.7)$ & $24( \pm 4.2)$ & $11( \pm 4.4)$ \\
\hline 2006-2007 & $31( \pm 2.0)$ & $20( \pm 2.5)$ & $27( \pm 3.4)$ & $16( \pm 5.2)$ & $27( \pm 2.1)$ & $18( \pm 3.0)$ & $26( \pm 2.4)$ & $15( \pm 4.1)$ & $25( \pm 3.3)$ & $12( \pm 5.5)$ \\
\hline 2007-2008 & $31( \pm 1.9)$ & $23( \pm 1.2)$ & $27( \pm 1.6)$ & $17( \pm 2.9)$ & $28( \pm 2.1)$ & $16( \pm 3.9)$ & $25( \pm 3.6)$ & $13( \pm 4.5)$ & $27( \pm 2.9)$ & $16( \pm 3.3)$ \\
\hline 2008-2009 & $29( \pm 2.8)$ & $20( \pm 3.8)$ & $26( \pm 2.7)$ & $15( \pm 4.0)$ & $25( \pm 2.0)$ & $15( \pm 3.4)$ & $25( \pm 3.3)$ & $12( \pm 3.7)$ & $24( \pm 3.3)$ & $11( \pm 4.2)$ \\
\hline 2009-2010 & $30( \pm 2.2)$ & $24( \pm 3.0)$ & $27( \pm 2.2)$ & $19( \pm 4.1)$ & $25( \pm 3.5)$ & $18( \pm 4.3)$ & $21( \pm 5.3)$ & $12( \pm 6.8)$ & $22( \pm 3.4)$ & $12( \pm 4.9)$ \\
\hline 2010-2011 & $30( \pm 1.4)$ & $19( \pm 1.7)$ & $27( \pm 2.3)$ & $16( \pm 3.6)$ & $22( \pm 4.6)$ & $8( \pm 4.7)$ & $24( \pm 3.0)$ & $11( \pm 4.5)$ & $26( \pm 2.8)$ & $13( \pm 3.0)$ \\
\hline \multicolumn{11}{|c|}{ Orlando, Florida } \\
\hline 2005-2006 & $28( \pm 3.6)$ & $19( \pm 5.0)$ & $26( \pm 2.9)$ & $15( \pm 3.0)$ & $21( \pm 3.0)$ & $10( \pm 3.5)$ & $24( \pm 3.6)$ & $11( \pm 4.7)$ & $23( \pm 4.7)$ & $10( \pm 5.1)$ \\
\hline 2006-2007 & $29( \pm 3.1)$ & $17( \pm 3.5)$ & $24( \pm 3.8)$ & $13( \pm 4.6)$ & $25( \pm 3.4)$ & $15( \pm 4.0)$ & $23( \pm 4.7)$ & $13( \pm 4.5)$ & $22( \pm 5.1)$ & $10( \pm 4.1)$ \\
\hline 2007-2008 & $30( \pm 2.4)$ & $22( \pm 2.0)$ & $26( \pm 2.5)$ & $14( \pm 3.4)$ & $25( \pm 3.4)$ & $14( \pm 4.0)$ & $22( \pm 4.6)$ & $11( \pm 4.7)$ & $25( \pm 3.6)$ & $13( \pm 4.3)$ \\
\hline 2008-2009 & $28( \pm 3.3)$ & $18( \pm 4.6)$ & $24( \pm 3.8)$ & $12( \pm 5.1)$ & $24( \pm 3.6)$ & $12( \pm 4.0)$ & $22( \pm 4.7)$ & $8( \pm 4.8)$ & $23( \pm 4.7)$ & $9( \pm 4.7)$ \\
\hline 2009-2010 & $30( \pm 3.5)$ & $20( \pm 3.9)$ & $26( \pm 3.5)$ & $16( \pm 4.0)$ & $22( \pm 4.8)$ & $13( \pm 5.0)$ & $18( \pm 6.4)$ & $7( \pm 6.0)$ & $17( \pm 4.4)$ & $8( \pm 4.2)$ \\
\hline 2010-2011 & $30( \pm 1.6)$ & $17( \pm 2.4)$ & $26( \pm 3.1)$ & $14( \pm 3.5)$ & $18( \pm 4.6)$ & $4( \pm 3.9)$ & $22( \pm 4.0)$ & $9( \pm 3.7)$ & $25( \pm 4.7)$ & $12( \pm 4.0)$ \\
\hline \multicolumn{11}{|c|}{ Gainesville, Florida } \\
\hline 2005-2006 & $26( \pm 4.1)$ & $17( \pm 6.2)$ & $24( \pm 3.5)$ & $11( \pm 3.5)$ & $18( \pm 3.4)$ & $5( \pm 3.5)$ & $20( \pm 4.3)$ & $8( \pm 6.0)$ & $19( \pm 4.9)$ & $6( \pm 5.5)$ \\
\hline 2006-2007 & $28( \pm 3.4)$ & $14( \pm 5.5)$ & $22( \pm 4.5)$ & $9( \pm 5.2)$ & $22( \pm 4.0)$ & $10( \pm 6.0)$ & $20( \pm 5.1)$ & $9( \pm 5.5)$ & $20( \pm 5.1)$ & $6( \pm 4.8)$ \\
\hline 2007-2008 & $28( \pm 3.3)$ & $19( \pm 3.4)$ & $23( \pm 2.9)$ & $9( \pm 5.0)$ & $22( \pm 4.6)$ & $9( \pm 4.5)$ & $18( \pm 5.4)$ & $7( \pm 5.6)$ & $23( \pm 3.9)$ & $8( \pm 5.7)$ \\
\hline 2008-2009 & $26( \pm 3.8)$ & $14( \pm 5.6)$ & $22( \pm 4.1)$ & $8( \pm 6.5)$ & $22( \pm 4.4)$ & $8( \pm 5.6)$ & $19( \pm 5.1)$ & $5( \pm 6.1)$ & $20( \pm 5.1)$ & $4( \pm 5.8)$ \\
\hline 2009-2010 & $29( \pm 3.9)$ & $18( \pm 5.5)$ & $23( \pm 3.2)$ & $12( \pm 4.7)$ & $18( \pm 5.3)$ & $9( \pm 5.8)$ & $16( \pm 6.3)$ & $3( \pm 6.9)$ & $16( \pm 4.3)$ & $4( \pm 4.9)$ \\
\hline 2010-2011 & $30( \pm 1.9)$ & $13( \pm 3.6)$ & $25( \pm 3.3)$ & $0( \pm 4.7)$ & $17( \pm 4.9)$ & $0( \pm 4.2)$ & $18( \pm 4.3)$ & $4( \pm 4.8)$ & $23( \pm 5.7)$ & $10( \pm 5.5)$ \\
\hline \multicolumn{11}{|c|}{ Aiken, South Carolina } \\
\hline 2005-2006 & $24( \pm 4.7)$ & $13( \pm 6.2)$ & $21( \pm 5.5)$ & $7( \pm 5.2)$ & $13( \pm 3.9)$ & $1( \pm 3.1)$ & $17( \pm 4.0)$ & $4( \pm 4.7)$ & $14( \pm 4.7)$ & $2( \pm 4.4)$ \\
\hline 2006-2007 & $23( \pm 4.8)$ & $10( \pm 5.5)$ & $19( \pm 5.2)$ & $6( \pm 3.9)$ & $17( \pm 5.1)$ & $4( \pm 5.7)$ & $15( \pm 5.3)$ & $3( \pm 6.1)$ & $14( \pm 5.3)$ & $1( \pm 4.1)$ \\
\hline 2007-2008 & $26( \pm 4.1)$ & $14( \pm 5.0)$ & $20( \pm 4.2)$ & $8( \pm 4.6)$ & $17( \pm 5.4)$ & $6( \pm 5.3)$ & $12( \pm 5.9)$ & $1( \pm 5.7)$ & $18( \pm 4.3)$ & $3( \pm 4.4)$ \\
\hline 2008-2009 & $23( \pm 4.9)$ & $10( \pm 5.4)$ & $17( \pm 4.5)$ & $4( \pm 5.8)$ & $19( \pm 5.3)$ & $6( \pm 7.2)$ & $14( \pm 5.1)$ & $2( \pm 6.0)$ & $16( \pm 5.4)$ & $1( \pm 5.7)$ \\
\hline 2009-2010 & $23( \pm 4.9)$ & $12( \pm 4.8)$ & $20( \pm 3.7)$ & $7( \pm 4.0)$ & $13( \pm 4.1)$ & $2( \pm 4.2)$ & $12( \pm 5.7)$ & $-1( \pm 5.7)$ & $12( \pm 4.2)$ & $0( \pm 3.3)$ \\
\hline 2010-2011 & $27( \pm 2.7)$ & $8( \pm 4.8)$ & $21( \pm 3.7)$ & $4( \pm 5.3)$ & $12( \pm 5.0)$ & $-3( \pm 4.2)$ & $12( \pm 5.8)$ & $-2( \pm 5.0)$ & $19( \pm 6.9)$ & $3( \pm 4.8)$ \\
\hline
\end{tabular}




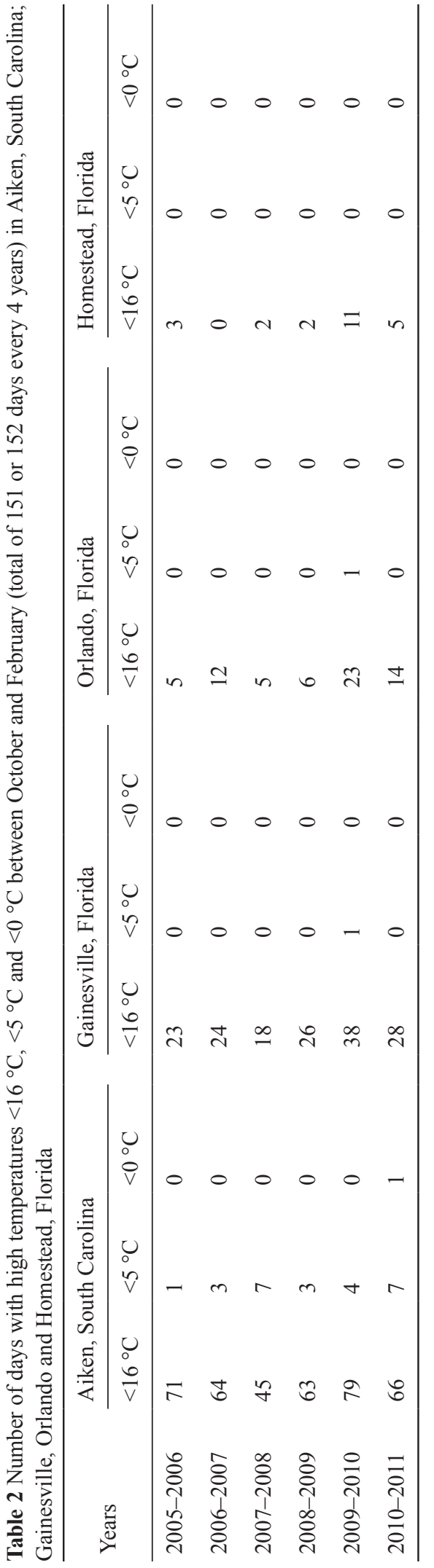

Homestead, monthly lows and highs (averaged for each of the 6 years) ranged from 12.5 to $22.7^{\circ} \mathrm{C}$ and 22.7 to $29.8{ }^{\circ} \mathrm{C}$, respectively (Table 1 ). In Aiken, mean lows ranged from 1.2 to $11.2{ }^{\circ} \mathrm{C}$, and highs ranged from 13.7 to $24.3{ }^{\circ} \mathrm{C}$ (Table 1). For all 4 sites, mean low and high $\mathrm{T}_{\mathrm{a}} \mathrm{s}$ were lowest during the months of January and February (Table 1). Over this 6 year span, the lowest mean monthly temperatures were recorded during the 20092010 and 2010-2011 seasons (Table 1).

The number of days between 1 October and 28 February for which high and low $\mathrm{T}_{\mathrm{a}} \mathrm{s}$ were less than or equal to 16,5 and $0{ }^{\circ} \mathrm{C}$ also increased northward among sites from Homestead to Aiken (Tables 2 and 3). From 2005 to 2011, Homestead experienced freezing temperatures 3 times (11 January 2010, 28 December 2010 and 29 December 2010), as $\mathrm{T}_{\mathrm{a}}$ of $0{ }^{\circ} \mathrm{C}$ or less were recorded for several hours each time. Northward, freezing temperatures were experienced yearly for 0-6 days (mean 3.7 days) in Orlando, 8-25 days (mean 15.7 days) in Gainesville and 36-65 days (mean 46.2 days) in Aiken (Table 2). There was 1 full day in Aiken when $T_{a}$ never exceeded $0{ }^{\circ} \mathrm{C}$ (Table 2). During this 5 month period, the projected $\mathrm{CT}_{\text {min }}$ of $5{ }^{\circ} \mathrm{C}$ for the Burmese python reached an average of $6.8,19.7,44$ and 88.7 days, respectively, for Homestead, Orlando, Gainesville and Aiken (Table 3). The number of complete days for which a python would not be able to digest its food $\left(\mathrm{T}_{\mathrm{a}} \leq 16^{\circ} \mathrm{C}\right)$ averaged 3.8, 10.8, 26.2 and 64.7 days, respectively, for Homestead, Orlando, Gainesville and Aiken (Table 2). In addition, digestion would be impaired ( $T_{a}$ reaching $16^{\circ} \mathrm{C}$ at some point in the day) for $70.3,95.2,129.5$ and 143.8 days, on average, for these 4 sites, respectively (Table 3).

To illustrate episodes when $\mathrm{T}_{\mathrm{a}} \mathrm{s}$ were above or below 16,5 and $0{ }^{\circ} \mathrm{C}$, we plotted daily high and low temperatures against these temperatures critical to Burmese python digestive physiology and survival (Figs 2-5). Each year, Homestead commonly experienced $\mathrm{T}_{\mathrm{a}} \mathrm{s}$ that dropped below $5{ }^{\circ} \mathrm{C}$ for short periods (1 day) in January, with additional days of $\mathrm{T}_{\mathrm{a}} \mathrm{s}<5{ }^{\circ} \mathrm{C}$ occasionally occurring in December and February (Fig. 2). Beginning in November and extending to the end of February, daily $\mathrm{T}_{\mathrm{a}} \mathrm{s}$ in Homestead would sporadically drop below $16^{\circ} \mathrm{C}$, usually for a 1 week span, although this occurred for as many as 6 continuous weeks in 2010-2011 (Fig. 2). Freezing temperatures were commonly reached in Orlando during January and occasionally in December and 
Table 3 Number of days with low temperatures $<16{ }^{\circ} \mathrm{C},<5{ }^{\circ} \mathrm{C}$ and $<0{ }^{\circ} \mathrm{C}$ between October and February (total of 151 or 152 days every 4 years) in Aiken, South Carolina; Gainesville, Orlando and Homestead, Florida

\begin{tabular}{|c|c|c|c|c|c|c|c|c|c|c|c|c|}
\hline \multirow{2}{*}{ Years } & \multicolumn{3}{|c|}{ Aiken, South Carolina } & \multicolumn{3}{|c|}{ Gainesville, Florida } & \multicolumn{3}{|c|}{ Orlando, Florida } & \multicolumn{3}{|c|}{ Homestead, Florida } \\
\hline & $<16^{\circ} \mathrm{C}$ & $<5^{\circ} \mathrm{C}$ & $<0^{\circ} \mathrm{C}$ & $<16{ }^{\circ} \mathrm{C}$ & $<5^{\circ} \mathrm{C}$ & $<0^{\circ} \mathrm{C}$ & $<16^{\circ} \mathrm{C}$ & $<5^{\circ} \mathrm{C}$ & $<0^{\circ} \mathrm{C}$ & $<16^{\circ} \mathrm{C}$ & $<5^{\circ} \mathrm{C}$ & $<0^{\circ} \mathrm{C}$ \\
\hline $2005-2006$ & 138 & 91 & 44 & 129 & 49 & 10 & 106 & 12 & 0 & 80 & 5 & 0 \\
\hline 2006-2007 & 149 & 85 & 36 & 124 & 33 & 8 & 101 & 9 & 0 & 56 & 7 & 0 \\
\hline $2007-2008$ & 141 & 83 & 31 & 126 & 34 & 10 & 95 & 25 & 6 & 53 & 2 & 0 \\
\hline 2008-2009 & 144 & 75 & 51 & 135 & 55 & 21 & 116 & 21 & 4 & 98 & 6 & 0 \\
\hline 2009-2010 & 142 & 90 & 50 & 123 & 52 & 20 & 96 & 25 & 6 & 60 & 8 & 1 \\
\hline 2010-2011 & 149 & 108 & 65 & 140 & 41 & 25 & 122 & 26 & 6 & 98 & 13 & 2 \\
\hline
\end{tabular}
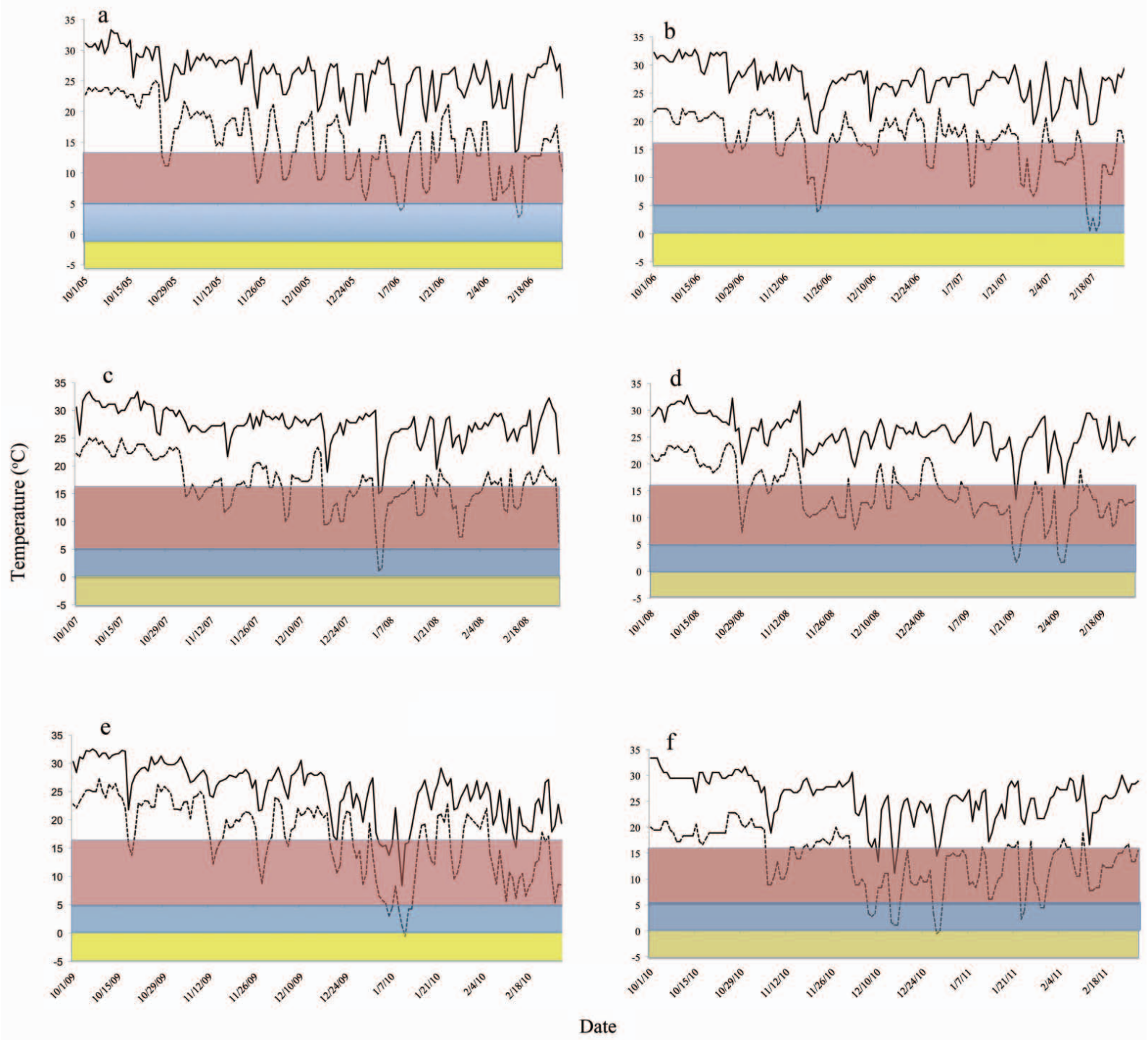

Figure 2 High (- ) and low (- - ) daily temperatures from October to February 2005 to 2011 for Homestead, Florida. The colored areas of each plot represent temperatures $<16{ }^{\circ} \mathrm{C}(\quad$ ), the temperature considered to be at the lower limits of digestion of the Burmese python, $<5{ }^{\circ} \mathrm{C}(\square)$, the temperature hypothesized to be at or near the critical thermal minimum of the Burmese python and $<0{ }^{\circ} \mathrm{C}$ ( ), the hypothesized lethal minimum temperature of the Burmese python. (a) October 2005 to February 2006; (b) October 2006 to February 2007; (c) October 2007 to February 2008; (d) October 2008 to February 2009; (e) October 2009 to February 2010; and (f) October 2010 to February 2011. 

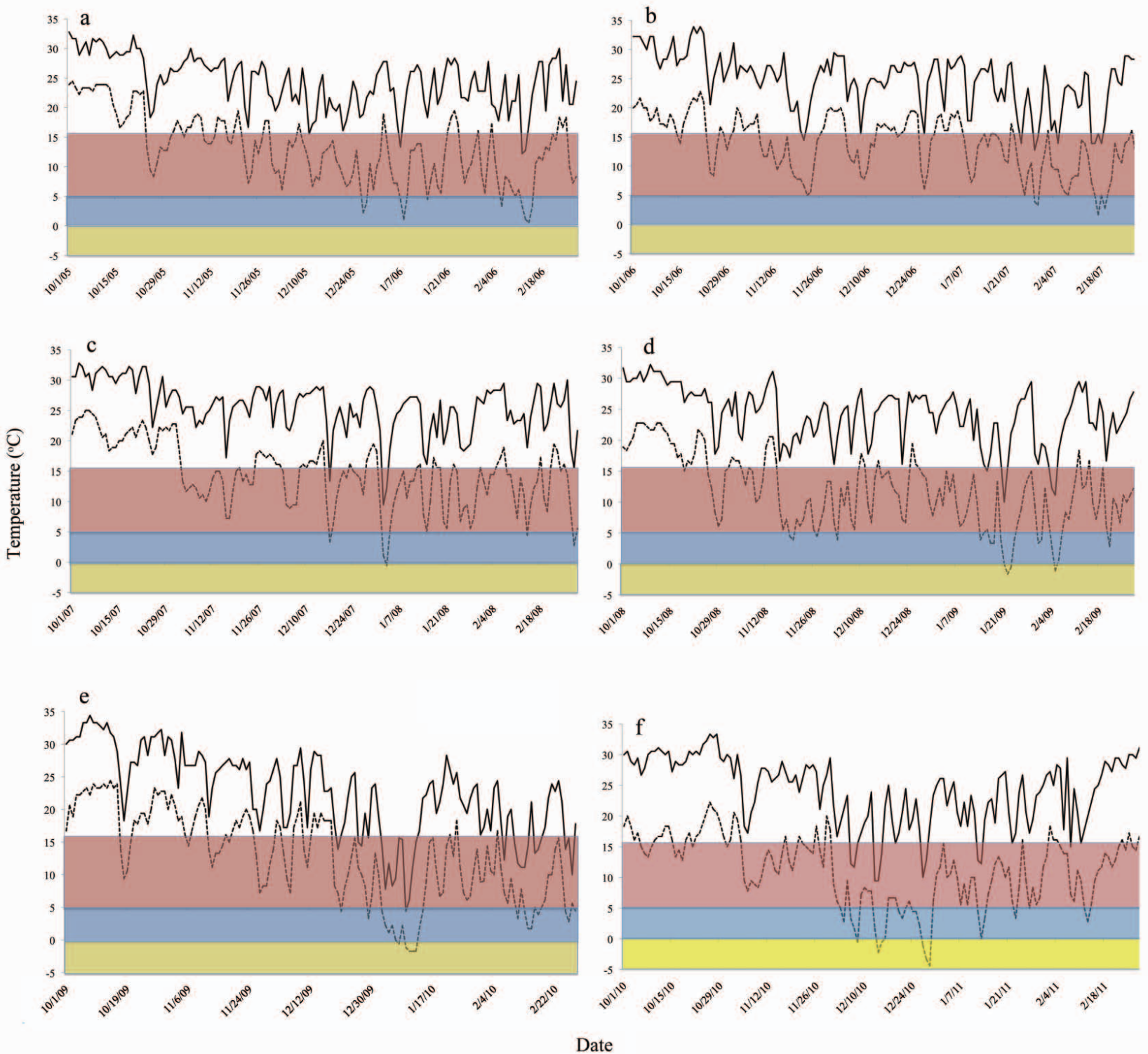

Figure 3 High (_) and low (- - ) daily temperatures from October to February 2005 to 2011 for Orlando, Florida. The colored areas of each plot represent temperatures $<16^{\circ} \mathrm{C}(\square)$, the temperature considered to be at the lower limits of digestion of the Burmese python, $<5{ }^{\circ} \mathrm{C}(\square)$, the temperature hypothesized to be at or near the critical thermal minimum of the Burmese python and $<0{ }^{\circ} \mathrm{C}$ ( $\quad$ ), the hypothesized lethal minimum temperature of the Burmese python. (a) October 2005 to February 2006; (b) October 2006 to February 2007; (c) October 2007 to February 2008; (d) October 2008 to February 2009; (e) October 2009 to February 2010; and (f) October 2010 to February 2011.

February (Fig. 3). In Orlando, $\mathrm{T}_{\mathrm{a}}$ dropped below $5{ }^{\circ} \mathrm{C}$ for a day or two as early as November (more than a week in January 2011) through December, January and February (Fig. 3). Almost daily from November to February,
$\mathrm{T}_{\mathrm{a}} \mathrm{s}$ in Orlando dropped below $16{ }^{\circ} \mathrm{C}$ (Fig. 3). In Gainesville, $\mathrm{T}_{\mathrm{a}}$ dropped below $0{ }^{\circ} \mathrm{C}$ twice each month from November to February (Fig. 4). From late October through February, Gainesville had a repeated pattern of a day or 

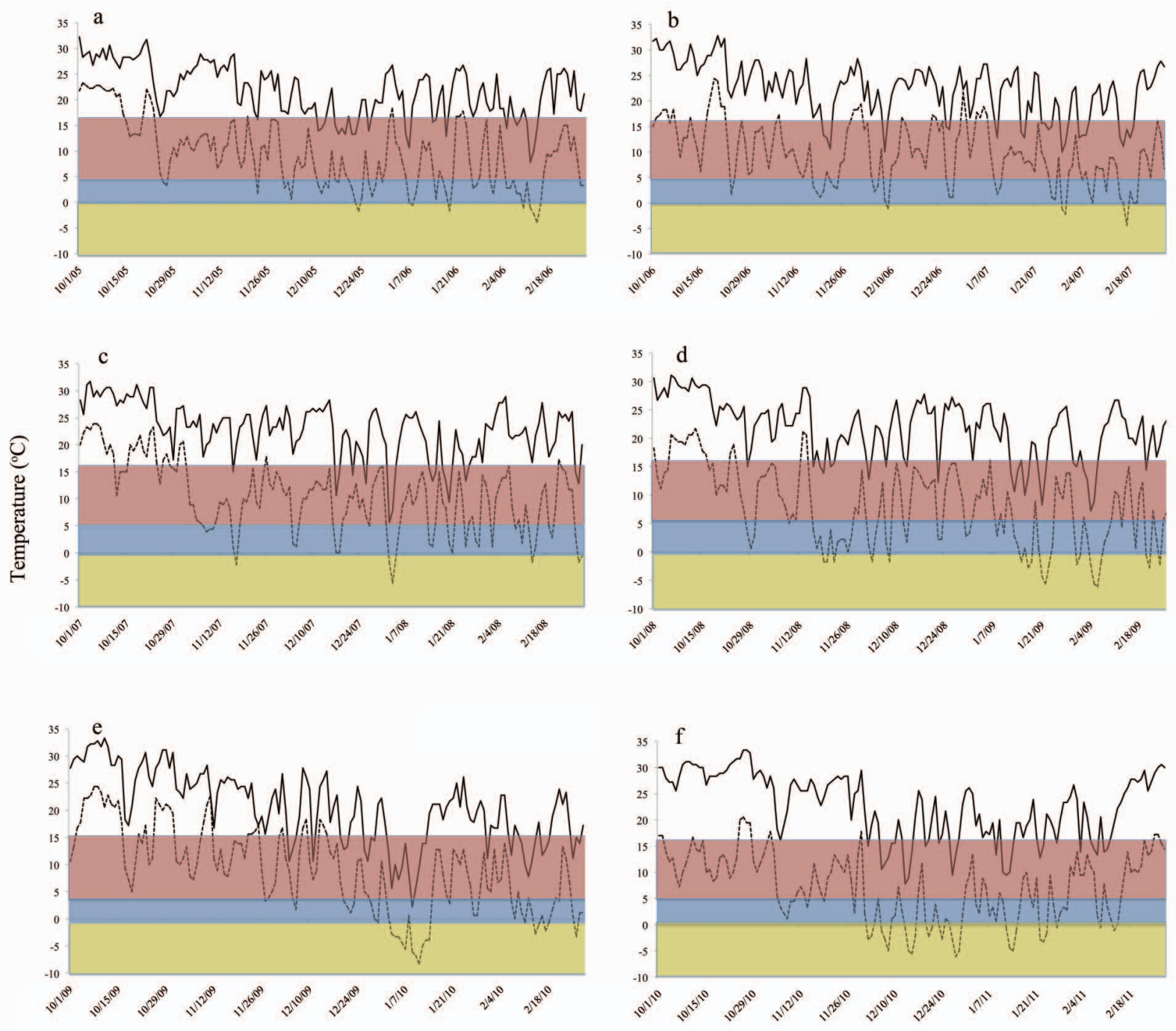

Date

Figure 4 High (_) and low (- - -) daily temperatures from October to February 2005 to 2011 for Gainesville, Florida. The colored areas of each plot represent temperatures $<16{ }^{\circ} \mathrm{C}($ ) , the temperature considered to be at the lower limits of digestion of the Burmese python, $<5^{\circ} \mathrm{C} \quad(\quad)$, the temperature hypothesized to be at or near the critical thermal minimum of the Burmese python and $<0{ }^{\circ} \mathrm{C}(\quad)$, the hypothesized lethal minimum temperature of the Burmese python. (a) October 2005 to February 2006; (b)October 2006 to February 2007; (c) October 2007 to February 2008; (d) October 2008 to February 2009; (e) October 2009 to February 2010; and (f) October 2010 to February 2011.

two when $\mathrm{T}_{\mathrm{a}}$ dropped below $16{ }^{\circ} \mathrm{C}$ followed by several days of warmer temperatures (Fig. 4). For much of November, December, January and February, daily $T_{a}$ in Gainesville dropped $<16{ }^{\circ} \mathrm{C}$, with numerous 1-12 day spans when $\mathrm{T}_{\mathrm{a}}$ never exceeded $16{ }^{\circ} \mathrm{C}$ (Fig. 4). The north- ernmost site, Aiken, encountered freezing temperatures (1 day-2 week spans) beginning in early November and continuing to the end of February (Fig. 5). From midOctober to February in Aiken, daily $\mathrm{T}_{\mathrm{a}}$ dropped an average of $59 \%$ of the days for the 5 months, and dropped 

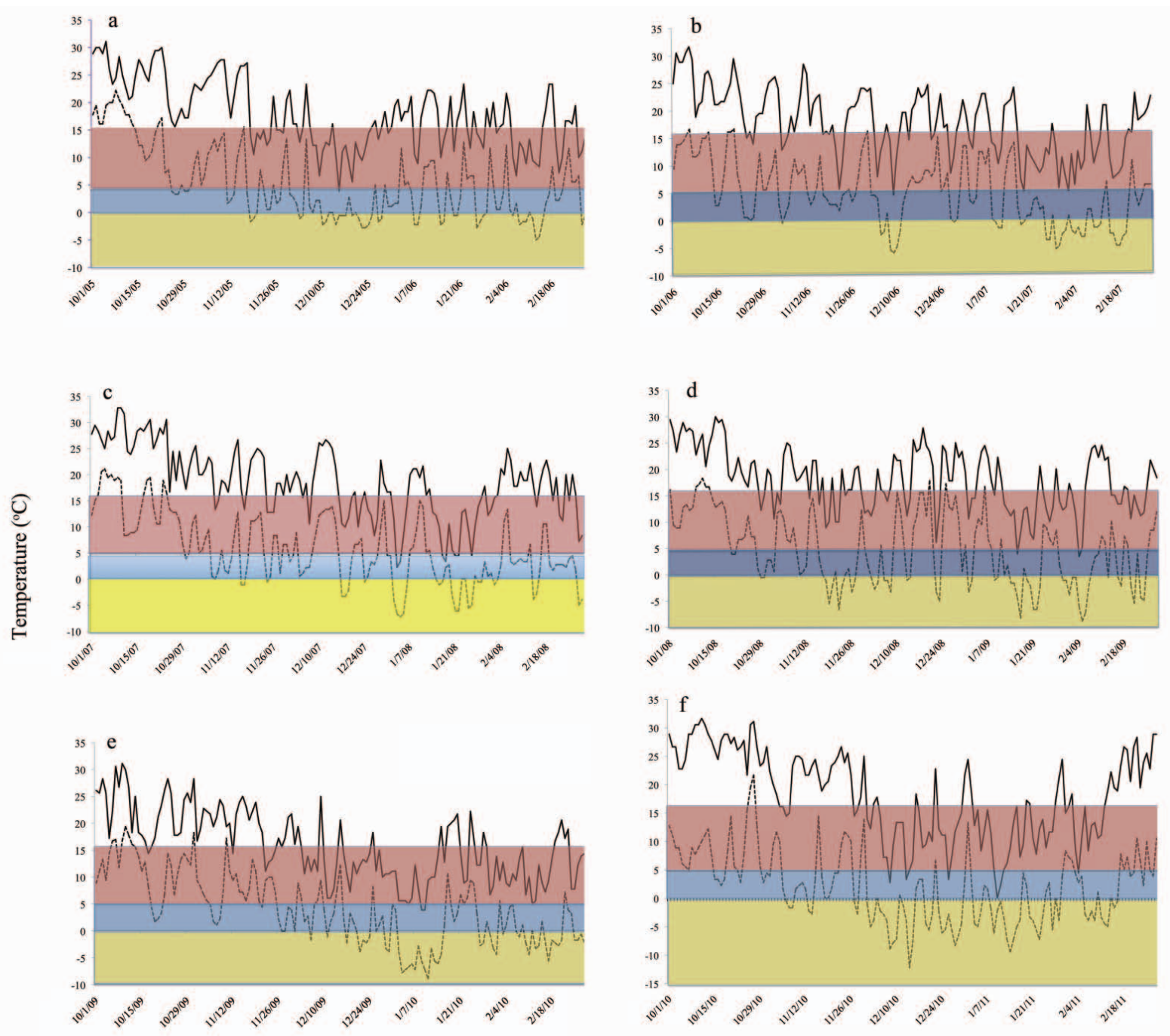

Date

Figure 5 High (_) and low (- - ) daily temperatures from October to February 2005 to 2011 for Aiken, South Carolina. The colored areas of each plot represent temperatures $<16{ }^{\circ} \mathrm{C}(\square)$, the temperature considered to be at the lower limits of digestion of the Burmese python, $<5{ }^{\circ} \mathrm{C} \quad(\quad)$, the temperature hypothesized to be at or near the critical thermal minimum of the Burmese python and $<0{ }^{\circ} \mathrm{C}(\quad)$, the hypothesized lethal minimum temperature of the Burmese python. (a) October 2005 to February 2006; (b)October 2006 to February 2007; (c) October 2007 to February 2008; (d) October 2008 to February 2009; (e) October 2009 to February 2010; and (f) October 2010 to February 2011.

below $5{ }^{\circ} \mathrm{C}$ for as long as 3 continuous weeks (Fig. 5). For the full 5 months in Aiken, only in early October did daily $\mathrm{T}_{\mathrm{a}}$ remain above $16^{\circ} \mathrm{C}$, and beginning in early November there were spans of 1-2 weeks when $T_{a}$ never exceeded $16{ }^{\circ} \mathrm{C}$ (Fig. 5).

\section{DISCUSSION}

Ambient temperatures recorded during October through February progressively decreased northward from Homestead to Aiken. For each site, $\mathrm{T}_{\mathrm{a}}$ (illustrated as daily lows and highs, Figs 2-5) declined from Octo- 
ber into January, the month that the lowest $\mathrm{T}_{\mathrm{a}}$ was generally recorded. February characteristically experienced an increase in $\mathrm{T}_{\mathrm{a}}$ and, by the end of February, $\mathrm{T}_{\mathrm{a}}$ had approached a range of values similarly recorded in October and early November.

One of the aims of this study was to identify the extent that Burmese pythons would be physiologically challenged thermally if they were located within 4 sites included within the projected range of their potential expansion from southern Florida as proposed by Rodda $e t$ al. (2009). The Homestead site is located $6 \mathrm{~km}$ east of the ENP and, thus, experiences a yearly $\mathrm{T}_{\mathrm{a}}$ profile nearly identical to that experienced by pythons inhabiting the Everglades. Based on our data for this site, Burmese pythons inhabiting the Everglades would rarely encounter freezing temperatures. For the past 6 years, short periods of freezing temperatures have only been recorded 3 times in Homestead, with $\mathrm{T}_{\mathrm{a}}$ dropping to $5{ }^{\circ} \mathrm{C}$ much more frequently, averaging 7 times a year for episodes of 12-36 h. Although such a temperature may not immediately kill a python, it would render it inactive and unable to defend itself against predators (e.g. foxes, coyotes, bobcats and cougars). From early or mid-November to February, Burmese pythons in the Everglades encounter $\mathrm{T}_{\mathrm{a}} \mathrm{s}$ above and below $16{ }^{\circ} \mathrm{C}$. Given the assumption that at this temperature and lower, pythons are unable to digest their food (even at $20{ }^{\circ} \mathrm{C}$, digestion is severely hampered [Wang et al. 2003]), we suspect that pythons are digestive quiescent during this part of the year.

Orlando is in central Florida, approximately $340 \mathrm{~km}$ north of Homestead. For the past 4 years, Orlando has experienced freezing temperatures several times each year (Table 3). On average, Orlando experienced approximately 20 days for which $\mathrm{T}_{\mathrm{a}}$ dropped to $5{ }^{\circ} \mathrm{C}$ and less. Pythons exposed to those low temperatures are likely to be susceptible to predation. From November to February, a free-ranging python inhabiting the Orlando area may have little opportunity to digest a meal given the thermal limitations to digestion (Fig. 3). Only $154 \mathrm{~km}$ north of Orlando, Gainesville experienced more than 4 times the number of days that $\mathrm{T}_{\mathrm{a}}$ dropped below $0{ }^{\circ} \mathrm{C}$ and twice the number of days with $\mathrm{T}_{\mathrm{a}}$ below $5{ }^{\circ} \mathrm{C}$ compared to Orlando (Table 3 ). Python activity and digestion would be largely inhibited during this 5 month period; almost every day, $\mathrm{T}_{\mathrm{a}}$ dropped below $16{ }^{\circ} \mathrm{C}$ and for more than half of this period, daily lows were at or below projected $\mathrm{CT}_{\min }\left(5^{\circ} \mathrm{C}\right)$. Aiken is approximately $450 \mathrm{~km}$ north of Gainesville and $920 \mathrm{~km}$ north of Homestead. The thermal and physiological challenges of a free- ranging python inhabiting the surrounding areas of Aiken may be quite severe, as freezing temperatures would be encountered regularly from December through February. Even outside of this period (Fig. 5), there were a number of days where daily temperatures either dropped below $16{ }^{\circ} \mathrm{C}$, thereby curtailing python digestion, or below $5{ }^{\circ} \mathrm{C}$, eliminating a Burmese python's ability to move and defend itself effectively.

\section{Thermal challenges and python survival}

Our premise that free-ranging Burmese pythons would be thermally challenged during the colder months of the year within the Everglades and at 3 sites further north is supported by 3 recent reports (Avery et al. 2010; Dorcas et al. 2011; Mazzotti et al. 2011). During a 1 to 2 week period of cold temperatures in early January 2010, $\mathrm{T}_{\mathrm{a}}$ within ENP, Florida dropped below $15{ }^{\circ} \mathrm{C}$ each day and maximum water temperatures stayed below $15{ }^{\circ} \mathrm{C}$ (Mazzotti et al. 2011). Minimum $\mathrm{T}_{\mathrm{a}}\left(<0{ }^{\circ} \mathrm{C}\right.$ ) was reached on the morning of 11 January, resulting in surface ice formation and the death of fishes, green iquanas, sea turtles, American crocodiles and manatees in southern Florida (Hallac et al. 2010). Of the 10 telemetered free-ranging Burmese pythons under study in the Everglades, 9 died during this cold spell (Mazzotti et al. 2011). Of an additional 99 non-telemetered snakes located in January of 2010, 40 were found dead, of which 27 deaths were presumed to have resulted from cold exposure (Mazzotti et al. 2011). The proportion (27\%) of snakes found that had succumbed to the cold temperatures likely underestimated the actual python cold-related deaths given that the probability of detecting a cryptic dead python would be less than that of encountering a live, active individual.

During this same cold spell (3-10 January 2010), nearly $50 \%$ of $\mathrm{T}_{\mathrm{a}}$ recorded in Gainesville was at or below $0{ }^{\circ} \mathrm{C}$ (Avery et al. 2010). For 9 adult Burmese pythons being maintained in individual outdoor enclosures at the United States Department of Agriculture, Animal and Plant Health Inspection Service, Wildlife Services, National Research Center (USDA/APHIS/WS) field station in Gainesville, 3 died during this cold episode. Of the 9, 4 had developed respiratory infections resulting in the euthanasia of 2 and the moving of the other 2 indoors (Avery et al. 2010). The remaining 2 snakes stayed in their heated hide boxes during this time and experienced no ill effects (Avery et al. 2010).

In a study to determine the survivorship of Burmese pythons in a more temperate area within the projected range of suitable habitat proposed by Rodda et al. (2009), 
10 male pythons were maintained together in an outdoor enclosure $(31 \times 25 \mathrm{~m})$ at the Savannah River Ecology Laboratory in Aiken County, South Carolina from July 2009 to January 2010 (Dorcas et al. 2011). These snakes had available to them large brush piles, a small pond, and underground refugia buried $1 \mathrm{~m}$ below the surface. Snakes were habituated to the enclosure starting in July and fed regularly until October (Dorcas et al. 2011). Beginning in December 2009, $\mathrm{T}_{\mathrm{a}}$ dropped below $5{ }^{\circ} \mathrm{C}$, and with the further decrease to $-0.4{ }^{\circ} \mathrm{C}$ on $11 \mathrm{De}-$ cember 2009, 5 of the 10 pythons died. Later, in December and early January, 3 additional snakes perished, and by mid-January the remaining 2 pythons died (Dorcas et al. 2011). Pythons were discovered dead on the surface, in the water, under cover and within the underground refugia (Dorcas et al. 2011).

At all 3 sites, subfreezing temperatures resulted in python death regardless of whether snakes had access to refugia that were above freezing temperatures or not. The winter of 2009-2010 was noted as being uncharacteristically cold in south Florida (Mazzotti et al. 2011) and any pythons living north of the Everglades would have had a poor chance for survival unless they were able to find warmer refugia. Was the winter of 20092010 a uniquely cold winter such that pythons would survive most winters? Such an argument could be made for the Everglades, which seldom experiences subfreezing temperatures (none were recorded in Homestead from October 2005 to January 2010). However, freezing temperatures were again recorded in Homestead in December 2010 and similar conditions would have been experienced in the Everglades. Orlando, Gainesville and Aiken likewise experienced an equal number of or more days of freezing temperatures during 2010-2011 compared to 2009-2010 (Table 3). Hence, the magnitude of death would predictably be matched for these 2 winters.

\section{Snakes surviving cold temperatures}

Numerous species of snakes inhabit temperate regions of the world (Greene 1997). With the onset of cold temperatures in the fall, temperate snakes move into underground refugia (below the frost line) and remain dormant (minimal activity and aphagic) until temperatures begin to warm up again in the spring and they emerge from either solitary shelters or communal hibernacula (Gregory 1982; Macartney et al. 1989). The duration of hibernation increases progressively northward (in the northern hemisphere), ranging from several months in southern regions of North America to as long as 9 months in Canada (Gregory 1982). For temperate snakes, hibernation is an adapted natural history trait that enables them to survive a period of the year when food is largely unavailable and temperatures are lethally low.

For the Burmese python to survive in even modestly temperate regions of North America (e.g. southern USA) would require that when exposed to decreasing temperatures they could retreat to underground refugia and remain there until temperatures increased. This is contingent on 2 factors. First, pythons need an adequate number of accessible refugia of sufficient size, depth and moisture content to ensure protection from freezing temperatures and dehydration. Second, pythons must possess the innate behavior to retreat into underground shelter with the onset of cold temperatures and remain there until temperatures warm up again. Unfortunately lacking are any accounts of the overwintering behavior of the Burmese python from northern portions of its natural range.

If pythons did use available refugia, neonate and juveniles would more than likely experience greater overwinter survival in having a greater number of accessible sites available, such as rodent burrows, natural fissures in rock and ground, and root cavities. For larger pythons, only a limited number of suitable underground refugia, such as burrows of gopher tortoises (Gopherus polyphemus Daudin 1802), skunks [Mephitis mephitis (Schreber, 1776)], raccoons [Procyon lotor (Linnaeus, 1758)] and foxes (red fox [Vulpes vulpes (Linnaeus, 1758)] and gray fox [Urocyon cinereoargenteus (Schreber, 1775)]) have been suggested as refugia from freezing temperatures (Reed \& Rodda 2009). A large adult snake $(50-75 \mathrm{~kg})$ would require a cavity not only large enough to accommodate its size but also wide enough for it to turn around. Furthermore, the ability to find underground shelter may still not guarantee overwinter survival for Burmese pythons. Pythons in the Aiken study that sought refuge in $1 \mathrm{~m}$ deep shelters still succumbed to cold temperatures (Dorcas et al. 2011).

Regardless of the availability of adequate refugia, the capacity of Burmese pythons to successfully overwinter in the presence of freezing temperatures would be inhibited if they lacked the behavioral plasticity needed to retreat underground with the onset of cold temperatures and to remain there until temperatures warmed up. One conclusion from the recent studies (Avery et al. 2010; Dorcas et al. 2011; Mazzotti et al. 2011) on the overwinter survival of Burmese pythons is that the population of Burmese pythons currently established in south Florida largely lacks the innate behaviors to retreat to 
and remain within underground refugia with the onset of decreasing fall temperatures. Drawn from published observations is that these snakes respond to decreasing temperatures by increasing surface basking efforts. Predictably, this is the adaptive tactic of these snakes to increase body temperature given the more limited $\mathrm{T}_{\mathrm{a}}$ range in their origin (subtropical Southeast Asia [Reed 2005]), and is the only behavior they use to thermoregulate. Rather than remain in a warmer refugia that might provide adequate thermal protection to survive the winter, these pythons continually expose themselves to cold and sometimes lethal temperatures in their attempts to increase body temperatures via basking. With the absence of possessing the inherent behaviors to retreat and remain below the frost-line during the winter, these pythons are likely to die due to hypothermia wherever temperatures routinely reach freezing.

\section{Burmese python's northern expansion}

While clearly established in the Everglades, the potential for the Burmese python to expand its distribution to more temperate regions of Florida as well as become established elsewhere in the USA has been examined via 3 SDMs. A climate-matching approach using temperature and rainfall data from localities proximate to the edge of the combined native distribution of both Indian (P. molurus molurus Linnaeus, 1758) and Burmese pythons generated a hypothetical range of suitable habitat that extended northward along the east coast to Virginia, west through the southern states, including Arkansas and Oklahoma, along the southern portions of New Mexico and Arizona, and north through central California (Rodda et al. 2009). In contrast, an ecological-niche model approach using data also originating from within the range of both the Indian and Burmese python concludes that the only suitable habitat for the Burmese python within the USA resides in southern Florida and southern Gulf edge of Texas (Pyron et al. 2008). In a third approach, using bioclimatic modeling, much of the southeastern USA and the western coastal Pacific Northwest of the USA and Canada are predicted to have suitable climate for the Burmese pythons (Van Wilgen et al. 2009).

Although these 3 models generated 3 very disparate outcomes, they share a similar fault by incorporating climate data from localities of considerable distance (2000-4000 km) from the source populations of Burmese pythons inhabiting southern Florida (Barker \& Barker 2010a,b; Engeman et al. 2011). Data used in the models originate from localities within the distribu- tion range of both the Indian and Burmese python. The Indian python ranges throughout India with limited extensions of the distribution into southeastern and northeastern Pakistan. It was essentially eliminated from import into the USA beginning in 1976 when it was listed as an endangered species in the USA (Federal Register 1976) and designated a CITES Appendix I status (CITES 2011). Although the range of the Burmese python extends eastward through Myanmar, Thailand, Laos, Cambodia and Vietnam and north into southern China, as well as portions of Indonesia, the individuals imported over the past 4 decades originate largely from Southeast Asia, initially from Thailand, then from Malaysia (where they do not occur in the wild) and, more recently (since 1995), from Vietnam (de Vosjoli \& Klingenberg 2005; D. G. Barker \& T. M. Barker, unpubl. data). Therefore, over the 10-20 years that Burmese pythons have established populations in the Everglades, either from accidental escape or purposeful release, they have originated directly or indirectly (via reproduction) from Southeast Asian populations (Snow et al. 2007). Revised SDMs that use climate data from localities within Southeast Asia (thus excluding data from India and China) predictably generate a more accurate hypothetical distribution of suitable habitat for the Burmese python in the USA.

A second problem with the above models is that they rely solely upon spatial environmental data for correlative distributional inferences. As has been pointed out by others (Kearney \& Porter 2009), SDMs can be developed that link spatial data with physiological responses of an organism to its environment. This might result in more robust prediction of the invasive ability of a species to a novel environment. Unfortunately, this approach requires detailed data on the physiological ecology of a species in its native environment, something that is lacking for the Burmese python and most other species of invasive reptiles.

A population genetics study using tissues collected from 156 Burmese pythons captured throughout the ENP found the population to be genetically homogenous and distinct genetically from pythons originating from Vietnam, suggesting that founder individuals originated (directly or indirectly) from Thailand (Collins et al. 2008). This is important to know because a recent study on the invasive brown anole (Anolis sagrei Duméril 1837), revealed that increased genetic diversity due to multiple introductions from different source populations may account for its ability to spread beyond predictions based on niche axes parameters for its native range (An- 
getter et al. 2010). Genetic mixing of invading populations might ultimately allow a fundamental niche shift and ability of an invasive species to spread (Kolbe et al. 2008; Alexander \& Edwards 2010). If additional DNA sequencing studies confirm the finding that Burmese python populations in southern Florida lack genetic diversity, then this might limit the ability of this snake to become established in more temperate areas of Florida and elsewhere in southern USA.

From the recent reports of winter death (Avery et al. 2010; Dorcas et al. 2011; Mazzotti et al. 2011), the coldtemperature challenges that Burmese pythons face for activity, digestion and overall survival, and the consideration that Burmese pythons have escaped or have been released in other areas of the USA, but have yet not become established, it appears unlikely that the Burmese pythons inhabiting the Everglades will be capable of expanding or becoming established far beyond southern Florida. Additional research to understand more clearly the possibility of northward range expansion should include definitive population genetics to verify the origin of the south Florida snakes (e.g. Thailand and Vietnam); manipulative trials under climate-controlled conditions to define the thermal limits of these snakes, not only with regard to their immediate survival but to impacts on health and reproductive potential; and trials in outdoor settings where the snakes are cold-challenged to document their specific thermoregulatory behavioral responses (e.g. seeking refuge and basking).

\section{ACKNOWLEDGMENTS}

The authors thank April Childress and Karen Scott, College of Veterinary Medicine, University of Florida, for technical assistance.

\section{REFERENCES}

Alexander JM, Edwards PJ (2010). Limits to the niche and range margins of alien species. Oikos 119, 137786.

Angetter L-S, Lotters S, Rodder D (2010). Climate niche shift in invasive species: the case of the brown anole. Biological Journal of the Linnean Society 104, 943-54.

Arnold S (1972). Species densities of predators and their prey. The American Naturalist 106, 220-36.

Avery RA (1982). Field studies of body temperatures and thermoregulation. In: Gans C, Pough FH, eds.
Biology of the Reptilia, vol. 12. Academic Press, NY, pp. 93-166.

Avery ML, Engeman RM, Keacher KL et al. (2010). Cold weather and the potential range of invasive Burmese pythons. Biological Invasions 12, 3649-52.

Barker DG, Barker TM (2010a). The distribution of the Burmese python, Python bivittatus, in China. Bulletin of the Chicago Herpetological Society 45, 86-8.

Barker DG, Barker TM (2010b). A critique of the analysis used to predict the climate space of the Burmese python in the United States by Rodda et al. (2008, 2009) and Reed and Rodda (2009). Bulletin of the Chicago Herpetological Society 45, 97-106.

Barker DG, Barten S, Ehrsam J, Daddono L (2012). The corrected lengths of 2 well-known giant pythons and the establishment of a new maximum length record for Burmese pythons, Python bivitattus. Bulletin of the Chicago Herpetological Society 47, 1-6.

CITES, Convention on International Trade in Endangered Species of Wild Fauna and Flora (2011). Checklist of CITES Species 2011. [Cited 17 July 2012.] Available from URL: http://www.cites.org/ eng/resources/species.html

Collins TM, Freeman B, Snow S (2008). Final report: genetic characterization of populations of the nonindigenous Burmese python in Everglades National Park. Final report for the South Florida Water Management District. Department of Biological Sciences, Florida International University, Miami, Florida.

Cowles RB, Bogert C (1944). A preliminary study of the thermal requirements of desert reptiles. Bulletin of the American Museum of Natural History 83, 26596.

Darlington PJ (1966). Zoogeography: The Geological Distribution of Animals. John Wiley and Sons, NY.

de Vosjoli P (1991). The General Care and Maintenance of Burmese Pythons, Including Notes on Other Large Pythons. Advanced Vivarium Systems, Lakeside, CA.

de Vosjoli P, Klingenberg R (2005). Burmese Python Plus Reticulated Pythons and Related Species. Advanced Vivarium Systems, Irvine, CA.

Dorcas ME, Willson JD, Gibbons JW (2011). Can invasive Burmese pythons inhabit temperate regions of the southeastern United States? Biological Invasions 13, 793-802.

Doughty P (1994). Critical thermal minima of garter snakes (Thamnophis) depend on species and body size. Copeia 1994, 537-40. 
Dove CJ, Snow RW, Rochford MR, Mazotti FJ (2011). Birds consumed by the invasive Burmese python (Python molurus bivittatus) in Everglades National Park, Florida, USA. The Wilson Journal of Ornithology 123, 126-31.

Engeman R, Jacobson E, Avery ML, Meshaka WE (2011). The aggressive invasion of exotic reptiles in Florida with a focus on prominent species: a review. Current Zoology 57, 599-612.

Federal Register (1976). Endangered and threatened wildlife and plants. Endangered Status for 159 Taxa of Animals 41, 24062-7.

Greene HW (1997). Snakes: The Evolution of Mystery in Nature. University of California Press, Berkeley, California.

Gregory PT (1982). Reptilian hibernation. In: Gans C, Pough FH, eds. Biology of the Reptilia, vol. 13. Academic Press, New York, pp. 53-154.

Hallac D, Kline J, Sadle J, Bass S, Ziegler T, Snow S (2010). Preliminary Effects of the January 2010 Cold Weather on Flora and Fauna in Everglades National Park. Biological Resources Branch, South Florida Natural Resources Center, Everglades and Dry Tortugas National Parks, Homestead, FL.

Huey R (1982). Temperature, physiology, and the ecology of reptiles. In: Gans C, Pugh FH, eds. Biology of the Reptilia, vol. 12. Academic Press, NY, pp. 25-67.

Jacobs HJ, Auliya M, Bohme W (2009). Zur taxonomie des dunklen tigerpythons, Python molurus bivittatus Kuhl 1820, speziell der population von Sulawesi. Sauria 31, 5-16.

Jacobson ER, Whitford WG (1970). The effects of acclimation on physiological responses to temperature in the snakes Thamnophis proximus and Natrix rhombifera. Comparative Biochemistry and Physiology 35, 439-49.

Kearney M, Porter W (2009). Mechanistic niche modelling: combining physiological and spatial data to predict species ranges. Ecology Letters 12, 1-7.

Kolbe JJ, Larson A, Losos JB, de Queiroz K (2008). Admixture determines genetic diversity and population differentiation in the biological invasion of a lizard species. Biology Letters 4, 434-7.

Krysko KL, Burgess JP, Rohford MR et al. (2011). Verified non-indigenous amphibians and reptiles in Florida from 1863-2010: outlining the invasion process and identifying invasion pathways and stages. Zootaxa 3028, 1-64.
Macartney JM, Larsen RLW, Gregory PT (1989). Body temperatures and movements of hibernating snakes (Crotalus and Thamnophis) and thermal gradients of natural hibernacula. Canadian Journal of Zoology 67, 108-14.

Mazzotti F, Cherkiss MS, Hart KM et al. (2011). Coldinduced mortality of invasive Burmese pythons in south Florida. Biological Invasions 13, 143-51.

Meshaka WE (2011). A runaway train in the making: the exotic amphibians, reptiles, turtles, and crocodilians of Florida. Monograph 1. Herpetological Conservation and Biology 6, 1-101.

Murphy JC, Henderson RW (1997). Tales of Giant Snakes: A Natural History of Anacondas and Pythons. Krieger Publications, Malabar, FL.

Peterson CR, Gibson AR, Dorcas ME (1993). Snake thermal ecology: the causes and consequences of body-temperature variation. In: Seigel RA, Collins JT, eds. Snake: Ecology and Behavior. McGraw Hill, New York, pp. 241-314.

Pyron RA, Burbrink FT, Guiher TJ (2008). Claims of potential expansion throughout the US by invasive python species are contradicted by ecological niche models. PLoS ONE 3: e2931.

Qian H (2010). Environment-richness relationships for mammals, birds, reptiles, and amphibians at global and regional scales. Ecological Research 25, 629-37.

Reed RN (2005). An ecological risk assessment of nonnative boas and pythons as potentially invasive species in the United States. Risk Anlysis 25, 753-66.

Reed RN, Rodda GH (2009). Giant constrictors: biological and management profiles and an establishment risk assessment for 9 large species of pythons, anacondas, and the boa constrictor. US Geological Survey Open File Report 2009-1202, US Geological Survey, Reston, VA.

Rodda GH, Jarnevich CH, Reed RN (2009). What parts of the US mainland are climatically suitable for invasive alien pythons spreading from Everglades National Park? Biological Invasions 11, 241-51.

Saint Girons H (1980). Biogéographie et évolution des vipères européennes. Compte Rendu Des Séances de la Société de Biogéographie 496, 146-72.

Schall JJ, Pianka ER (1978). Geographical trends in numbers of species. Science 201, 679-86.

Shine R, Madsen T (1996). Is thermoregulation unimportant for most reptiles? An example using water 
pythons (Liasis fuscus) in tropical Australia. Physiological Zoology 69, 252-69.

Snow RW, Krysko KL, Enge KM, Oberhofer L, WarrenBradley A, Wilkins L (2007). Introduced populations of Boa constrictor (Boidae) and Python molurus bivittatus (Pythonidae) in southern Florida. In: Henderson RW, Powell R, eds. Biology of the Boas and Pythons. Eagle Mountain Publishing, Eagle Mountain, Utah, pp. 417-38.

Van Mierop LHS, Barnard SM (1978). Further observations on thermoregulation in the brooding female $P y$ thon molurus bivittatus (Serpentes, Boidae). Copeia 1978, 615-21.
Van Wilgen NJ, Roura-Pascual N, Richardson DM (2009). A quantitative climate-match score for risk assessment screening of reptile and amphibian introductions. Environmental Management 44, 590-607.

Vinegar A, Hutchinson VH, Dowling HG (1970). Metabolism, energetics, and the thermoregulation during brooding of snakes of the genus Python (Reptilia, Boidae). Zoologica 55, 19-48.

Wang T, Zaar M, Arvedsen S, Vedel-Smith C, Overgaard $\mathrm{J}$ (2003). Effects of temperature on the metabolic response to feeding in Python molurus. Comparative Biochemistry and Physiology A 133, 519-27. 